\title{
Cyprinella alvarezdelvillari, a New Cyprinid Fish from Río Nazas of México, with a Key to the Lepida Clade
}

\section{Salvador Contreras-Balderas and María de Lourdes Lozano}

\begin{abstract}
Cyprinella alvarezdelvillari is a new species of cyprinid fish described from Arroyo del Peñon de Covadonga headwaters (Balneario La Concha springs to 8 km downstream), Río Nazas, Durango, México. It is a dwarfed member of the lepida species group, differing from all others by the following characteristics: eye diameter larger than length of snout; heavy tuberculation over most of body and fins in breeding males, especially chin and center of dorsal area of pectoral fin; small spines on lips, on uppermost peduncle scale row, and over entire lachrymal; breast naked; a short vomer; lateral dark band as wide as eye or wider, most noticeable at midbody. Breeding males golden to reddish bronze on body, brighter on cheek and opercular area, with white borders on anal and paired fins; and a black overcast at peak breeding colors, caused by appearance of sparse large melanophores. Comments are presented on other members of the group, and a key is provided for their identification.

Cyprinella alvarezdelvillari n. sp. de pez ciprínido, se describe del Arroyo del Peñón de Covadonga (Ojo del Balneario La Concha, a 8 km río abajo), en el Río Nazas de Durango, México. Es un miembro enanizado del grupo de especies lepida; difiere de todos ellos por tener: ojo mayor que el rostro; tuberculación fuerte en todo el cuerpo y aletas, especialmente el centro dorsal de la aleta pectoral, mentón, y espinoletas en los labios; vomer corto; su estola es igual o mas ancha que el ojo, sobre todo al centro del cuerpo; espinoletas en la hilera superior de escamas del pedúnculo, así como en todo el lacrimal; pecho sin escamas; machos maduros dorado a bronce rojizos, más brillante en la mejilla y área opercular; bordes blancos en aletas pares y anal; machos negruzcos conforme al grado de maduréz por la aparición de grandes melanóforos dispersos. Se presentan comentarios sobre otras especies del grupo con una clave para identificación de sus especies.
\end{abstract}

$\mathrm{T}$ he cyprinid fishes of North America are a complex group with poorly defined genera. This is reflected in the speciose group formerly recognized as Notropis. This group has been repeatedly split and merged into several subgroups, often considered genera or subgenera (reviewed by Mayden, 1989); we follow him and Matthews (1987) in recognizing Cyprinella as distinct genus. One of its subgroups, the lepida species group of Mayden (1989), is composed of C. lepida Girard (1857) from the Edwards Plateau of Texas, and five Río Grande basin forms: $C$. rutila (Girard, 1857) from Río San Juan; C. proserpina (Girard, 1857) from Río Pecos and NE Coahuila; $C$. xanthicara (Minckley and Lytle, 1969), from the Cuatro Ciénegas basin; C. panarcys (Hubbs and Miller, 1978) from Río Conchos, and an undescribed form from the Río Salado (Hubbs and Miller, 1978). All are strictly allopatric, occupying discrete subbasins of the Río Grande, except $C$. lepida. The Plio-Pleistocene Río Grande included several now isolated interior basin complexes, such as Laguna de Guzmán and Laguna de Mayrán
(Meek, 1903, 1904; Farrington, 1904). This whole system is inhabited by the same or closely related fish groups (Meek, 1904), collectively named the Río Grande fish fauna (Smith and Miller, 1986). Hence, it was a welcome surprise to collect a new and distinctive species of the lepida species group in the Rio Nazas-Laguna de Mayrán basin. It is outstanding in that it inhabits a relatively well-explored area of northern México, known to one of us (SCB) since 1963. Once the new species was recognized, we found a few young specimens confused with $\mathrm{Co}$ doma ornata or Cyprinella garmani, in several former collections dating back to 1952 (one specimen) and 1968, always very scarce. This species provides further evidence that a portion of the Río Nazas basin fauna has been derived from Río Grande fish fauna.

\section{Methods}

Counts and measurements are as described by Hubbs and Lagler (1964), except the following: scales around body and caudal peduncle, 
taken as indicated in Chernoff and Miller (1982); predorsal scales were counted as rows crossing a line from the upper insertion of the gill cover to the dorsal-fin origin, not including single scales (Contreras-Balderas, 1975). In circumferential scale counts, the most common count is reported as $x-2-x$, with the first number for the scales above lateral line, the second for the lateral-line scales, and the third for the scales below lateral line; and the total is their sum. Gillraker count refers to the total on first arch. Institutional acronyms follow Leviton et al. (1985) and Leviton and Gibbs (1988). We use the terms tubercles for the larger pearl organs, tuberclets for those about half former, and spinelets to tiny ones on fins and scale margins. Under Material Examined, CS means cleared and stained.

\section{Cyprinella alvarezdelvillari $\mathrm{n}$. sp. Sardinita bronze del Nazas. Figures 1-4. Tables 1-4.}

Cyprinella sp., Sardinita Nazas, Williams et al., 1989:4 (survival status); Espinoza et al., 1992 (copied).

Holotype.-UANL 8302 (39.6 mm SL), tuberculate male, coll. at Balneario La Concha, $9 \mathrm{~km}$ SW Peñón Blanco, Durango, México; S. Contreras-Balderas and FCB group (SCB 88-58; 21V-88).

Paratypes.-UANL 8303 (276:13.4-43.8 mm $\mathrm{SL})$ and UANL 11131 (2; 32.6-36.5 mm SL: CS); same data as holotype; from this series, paratypes are deposited at AMNH 47834 (4); UNAM (IBCML-P) 3239 (4); UMMZ 214693 (8); and CAS (4, in transit). UANL 8310 (192: 21.4-36.0 mm SL); from Arroyo en Balneario Belém, $7 \mathrm{~km}$. SE Peñón Blanco; same colls. and date (from this series four paratypes each are at BMNH (in transit), IPN P4436, TU 157269, TNHC 17459, USNM 308111, and UALA 9115.01. Other paratypes: UANL 8315 (12: 23.2-36.5 mm SL); Arroyo 3.1 km SW Peñón Blanco; S. Contreras-Balderas and FCB group (SCB 81-25; 29-VIII-81). UANL 8316 (1:33.5 $\mathrm{mm} \mathrm{SL})$; Arroyo $1 \mathrm{~km}$. SE Peñón Blanco; S. Contreras-Balderas and FCB group (SCB 6863: 17-VIII-68). UANL 8266 (1:33.4 mm SL); Balneario La Concha; M. L. Lozano-Vilano and FCB group (MLLV 88-8; 6-V-88). CAS 54426 (1: $34.3 \mathrm{~mm}$ SL); Río del Peñón de Covadonga at La Concha; S. Weitzman and A. Solórzano (SW VIII:01:52-1).
Diagnosis.-A dwarf species Cyprinella (maximum SL $43.8 \mathrm{~mm}$ ); a member of the lepida species group characterized by eye diameter larger than snout length; naked breast; very oblique mouth; heavy tuberculation especially on central dorsum of pectoral fins of breeding males, on chin, and spinelets on lips. Mature breeding males with bronze underparts including fins; anal and paired fins with white borders; body dark, including venter, with large, sparse melanophores, most noticeable in mature males; both sexes with lateral band as wide or wider than eye, especially around midsides in females.

Description.-Physiognomy of Cyprinella alvarezdelvillari $\mathrm{n}$. sp. appears in Figure 1. It is a relatively dwarfed form, maximum SL $43.8 \mathrm{~mm}$, usually less than $36.0 \mathrm{~mm}$; SL of mature males from $25.0 \mathrm{~mm}$. Body strongly compressed, especially males, tapering to a relatively slender caudal peduncle. Dorsal profile more convex than ventral one, a body form that suggests a near-bottom swimmer. Dorsal origin nearly midway between nostrils and caudal base. Head rather robust, occupying more than half of predorsal length, and subequal to body depth in females and young males; head length tends to become relatively shorter as males grow and mature. Snout convex, not protruding over upper lip. Eye diameter longer than snout length (Fig. 2). Mouth terminal, very oblique; upper lip scarcely including lower lip, anteriorly below lower level of eye, and ending under a vertical less than midway between anterior margin of orbit and pupil. Body measurements appear in Table 1 .

Lateral line complete, rarely with pores missing on 1-2 scales; line strongly decurved behind opercle, leveling back about mideye level, and rising toward middle of the caudal peduncle from a point above anus. Cephalic lateral-line components highly variable. Supratemporal canal often missing on one or both sides, usually interrupted at midline, with $0-3$ pores; supraorbital canal pores variable, 6-10, often not connected to cephalic lateralis; infraorbital canal usually interrupted behind eye or not connected to lateralis, with $9-15$ pores; preopercular canal 5-11 pores, with several interruptions, especially in the jaw area; mandibular segment not connected through symphysis, 3-5 pores; at least one specimen with the infraorbital and preopercular canals fused behind eyes; sometimes canals with blind branches. Scales thin, moderately imbricate, slightly crowded in predorsal area, reduced in size toward naked breast; scales generally oval, their exposed fields with characteristic higher- 


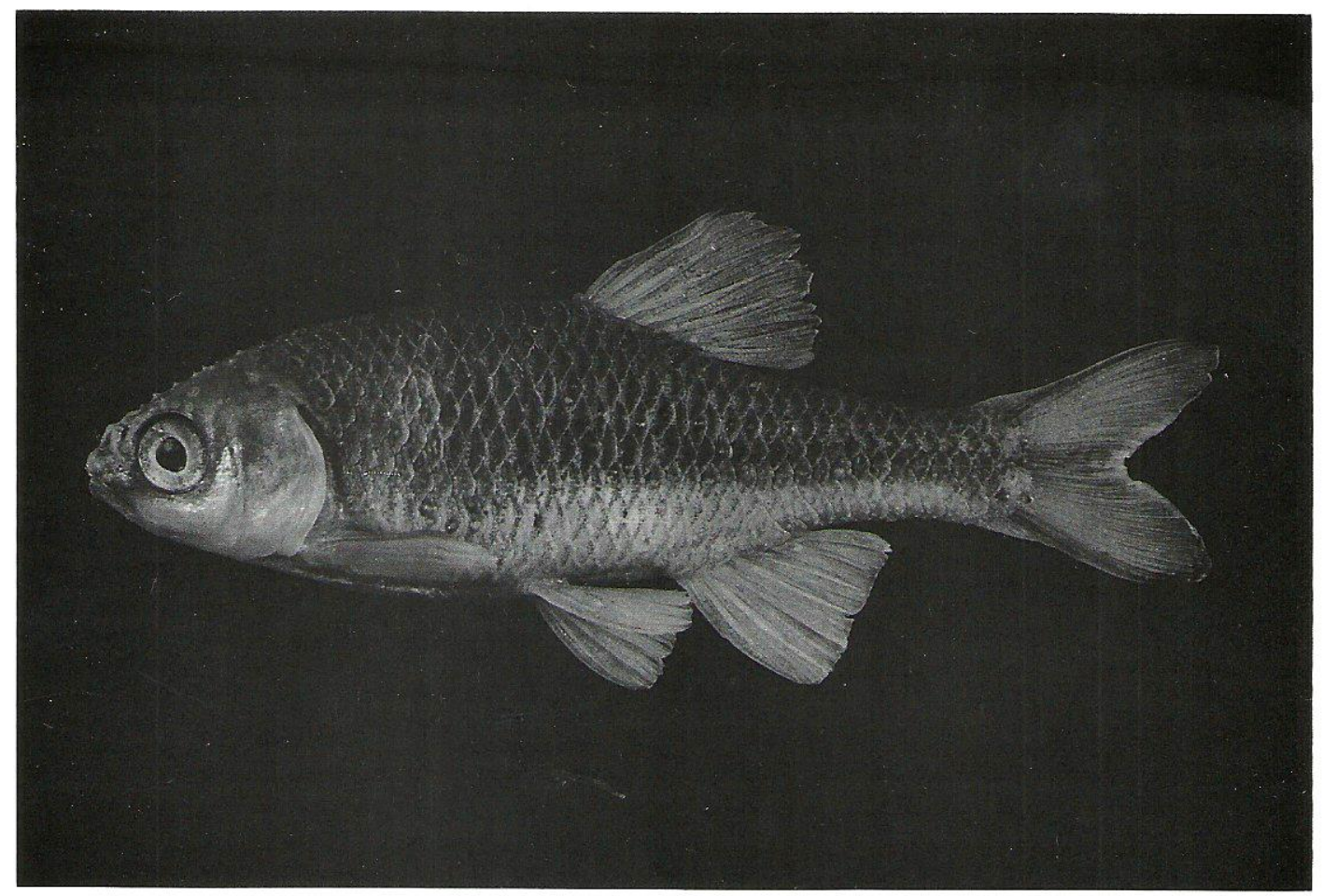

Fig. 1. Cyprinella alvarezdelvillari $\mathrm{n}$. sp.; Holotype UANL 8302 (39.6 mm SL), nuptial tuberculate male, from Balneario La Concha, 9 km SW Peñón Blanco, Durango, México.

than-wide diamond shape, enhanced by pigmentation.

Intestine simple S-shape, Type I of Kafuku (1958). Gillrakers on first arch short to rudimentary; counts in 20 paratypes 7 (4), 8(8), 9(5), and $10(3), \bar{x}=8.4$; pharyngeal teeth $4-4$, the upper three with strong hooks, masticatory surfaces relatively long and narrow; the lower tooth pointed, with no flat area. In older specimens, the masticatory surface tends to erode and leave weak points. The full arch is relatively short and wide.

Scale counts on 31 or 21 specimens, both including holotype (marked by $*$ ), are as follows: lateral-line scales $31(1), 33(15), * 34(12)$, $35(2)$, or $37(1), \overline{\mathrm{x}}=33.6$; circumferential scales above lateral line $12(1), * 13(11), 14(5)$, or 15 (4), $\overline{\mathrm{x}}=14.6$; circumferential scales below lateral line $10(4), * 11(16)$, or $12(1), \overline{\mathrm{x}}=10.6$; total circumferential scales $25(2), * 26(8), 28$ (8), or 29 (3), $\overline{\mathrm{x}}=27.1$; most common count *13-2-11. Caudal peduncle scales above lateral line $5(1)$, or $* 7(20), \overline{\mathrm{x}}=6.9$; caudal peduncle scales below lateral line $* 5$ (21); total caudal peduncle scales, $* 14(26)$, or $15(5), \overline{\mathrm{x}}=14.2$; most common count $* 7-2-5$. Scales between dorsal-fin origin and lateral line $6(3)$, or *7 (28), $\overline{\mathrm{x}}=6.9$; between anal fin and lateral line 3 (3),
*4 (15), or 5 (13), $\overline{\mathrm{x}}=4.3$; between lateral line and pelvic fin origin 3 (2), or $* 4(29), \bar{x}=3.9$. Fin-ray counts are as follows: dorsal-fin rays $* 8(30)$, or $9(1), \overline{\mathrm{x}}=8.03$; anal-fin rays $* 8(31)$; caudal-fin rays 18 (3), or $* 19(28), \overline{\mathrm{x}}=18.9$; pectoral-fin rays $11(25)$ or $* 12(37), \overline{\mathrm{x}}=11.6$; pelvic-fin rays 7 (12) or $* 8(50), \overline{\mathrm{x}}=7.8$.

Some osteological characters are as follows, with numbers as in Mayden (1989): (1) Frontals slighthly broadened; (2) junction of sphenotic and frontals not moved anteriorly; (3) ceratobranchial two with a long and thin neck; (4) vomer not extending beyond posterior edge of lateral ethmoid; (5) infraorbitals two or three entire or may be broken into two or three segments (one specimen had the IO 2 subdivided in two on one side and three on the other side); (6) dermopterotic side nearly vertical; (7) coronoid process of dentary narrow and elongate; (8) retroarticular L-shaped; (9) retroarticular long; (10) lateral margin of pharyngobranchial 2-3 expanded into small shelf; (11) uroneural 3 short, except one specimen had it long. Other characters are as follows: no autopterotic spine, vomer with deep anterior notch, with a short anterior basihyal ligament; temporal with a downward spine.

Males of this species are highly tuberculate 


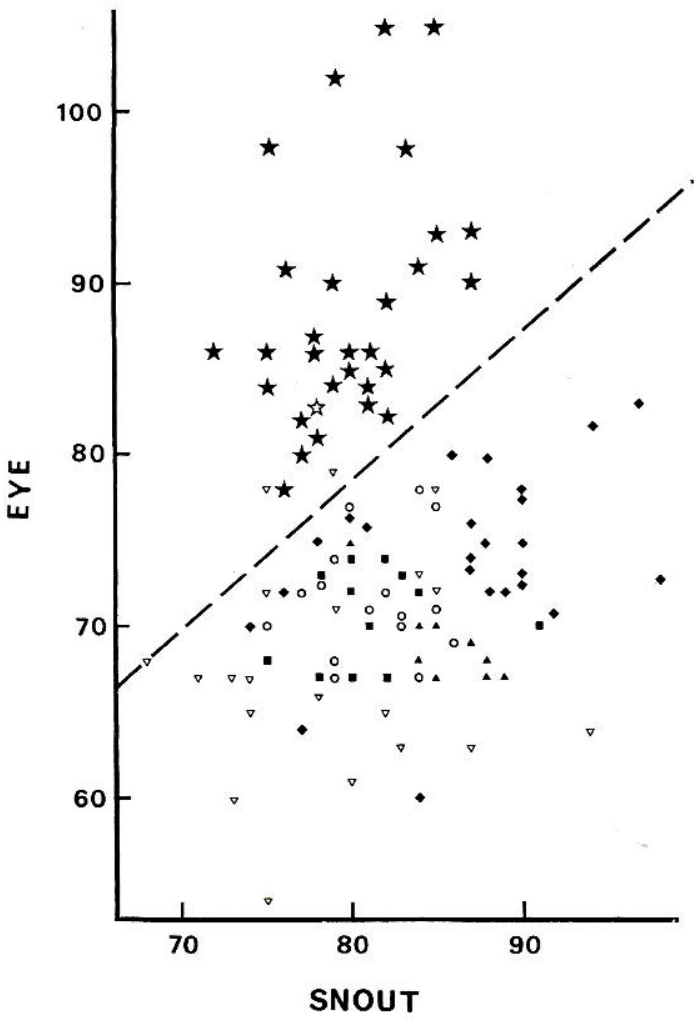

Fig. 2. Scatter plot of eye diameter compared to snout length in Cyprinid fishes of the genus Cyprinella, rutila-proserpina group. Symbols: $\star$ is $C$. alvarezdelvillari n. sp., Río Nazas (eye larger); $\Delta$ C. rutila, Río San Juan; $\nabla$ Cyprinella sp., Río Salado; $C$ C. proserpina, Río Pecos and associated small drainages; - C. xanthicara, Cuatro Cienegas; $\diamond$. panarcys, Rio Conchos. Measurements in permillage of standard length. Hollow star $=$ holotype. Solid stars $=$ paratypes.

at breeding season. Mature males nearly covered by tubercles. Those on top of head large, usually antrorse to nearly straight, swollen basally, in 2-6 irregular longitudinal rows, and surrounded by spinelets over entire surface; a close series of preorbitals and supraorbitals, 12 rows of supralabials; a hiatus between them and rostrals; lachrymal with some spinelets on all fields; predorsal tubercle patch from nape to a point that may reach the dorsal origin, usually shorter, but may reflect a difference in maturity; body scales with a marginal row of spinelets; caudal peduncle with tuberclets all around, including a few spinelets on middorsal scale row; a patch of tubercles along the ventral area, covering 1-2.5 scales above midventrals, or up to three scale rows above midanal base. No tuberclets posterior and below from eye. Lips with irregular rows of tuberclets. Chin with tuberclets, larger ones near symphysis, smaller at sides and back to the isthmus. Some details of head
TABle 1. MORPHOMETRY OF Cyprinella alvarezdelvillari N. SP., from Río Nazas, Durango, MÉxico. Measurements in parts per thousand of SL. Averages in parentheses.

\begin{tabular}{lcc}
\hline & Holotype & \multicolumn{2}{c}{ Paratypes } \\
\hline Standard length (mm) & 39.6 & $26.6-38.3$ \\
Predorsal length & 566 & $534(554) 580$ \\
Body depth & 328 & $267(291) 338$ \\
Caudal peduncle depth & 116 & $100(111) 128$ \\
Lateral line to & & \\
$\quad$ Dorsal-fin origin & 215 & $165(185) 223$ \\
$\quad$ Pelvic-fin origin & 111 & $89(106) 123$ \\
Head measurements & & \\
$\quad$ Head length & 293 & $263(280) 295$ \\
Head depth & 238 & $206(221) 239$ \\
Head width & 157 & $138(149) 164$ \\
Mouth width & 61 & $51(57) 63$ \\
Interorbital & 101 & $100(104) 113$ \\
Snout length & 78 & $72(79) 87$ \\
Eye diameter & 83 & $80(87) 102$ \\
Suborbital & 40 & $38(45) 58$ \\
Upper jaw length & 73 & $70(77) 84$ \\
Lower jaw length & 83 & $79(97) 109$ \\
Fin measurements & & \\
$\quad$ Depressed dorsal & 273 & $216(253) 284$ \\
Pectoral length & 202 & $158(190) 228$ \\
\hline
\end{tabular}

tuberculation may be seen on Figure 1 and on pectoral-fin rays in Figure 3. Dorsal, anal, and caudal fins with abundant and scattered spinelets, in single row on first ray and two per segment, followed by $4-5$ rays densely tuberculate especially around central area; pectorals similar, with spinelets being on dorsal surface, especially near middle of fin, where there may be 3-8 per segment, larger near the center of patch and anteriorly on each segment; pelvics usually with two spinelets per segment, in one row per ray. Females similarly tuberculate but more sparse and composed only of spinelets, tending to have few or none on fins.

Melanophore pigmentation is characteristic for this species, because most of the fish is covered by large melanophores, especially on males, providing them a sooty to spotty appearance superimposed upon the deeper basic pattern of dark head and dorsum. Body pigmentation in females is similar, but less marked, rarely with melanophores under lateral line, giving a blackand-white aspect. The typical diamond pattern on scale pockets is most strongly marked near midbody and obsolete on breast, where only large and sparse melanophores remain. Both sexes with jet black lateral band, as wide (females) or wider (males) than eye, especially near 
midbody; band may not be obscured in sooty males; band starts just behind opercle origin and extends to caudal base. Humeral bar present, diffuse or poorly marked, fused to lateral band, obsolete in young fish. Fin pigmentation as follows: all fin rays with melanophores, especially dense and dark on first rays (splint and first principal ray); males with comet caudal (upper and lower undivided rays darker); interradial membranes usually clear or with some scattered large melanophores, except dorsal fin of mature males, where melanophores tend to form a postdorsal blotch. The few ventral large melanophores are concentrated in gular region, interpelvic area, around anus, and along anal base.

Live color.-Nuptial males with an outstanding bright orange-bronze color, including fins; undersides of head and breast brighter; pectoral, pelvic, and anal fins with a pure white border almost as wide as pupil. Maturity is accompanied by a general blackening; at peak breeding condition adult males look almost black. Females drab dark green above, with whitish underparts.

Etymology.-The specific epithet is genitive, to honor the late José Alvarez del Villar, founder of modern Mexican ichthyology, who trained many generations of ichthyologists at Instituto Politécnico Nacional. He was an example to follow. We dedicate this species to him in memory of his teaching, his friendship, and his many contributions to our understanding of Mexican freshwater fishes.

Comparison.-We assign Cyprinella alvarezdelvillari $\mathrm{n}$. sp. to the lepida species group on the basis of 10 of the 12 characters defined by Mayden (1989); the characters that are not present in the new species are a vomer that does not extend beyond posterior edge of lateral ethmoids and apparent absence of the purplish shade on breeding males, which may be unnoticed because they turn dark to black over orange yellow. Also, they present the following characters in common: whitish pigment on fins, eight anal rays (except lepida, that has nine), long dark gular streak reaching branchiostegal membranes (except lepida, with short gular bar), 4-4 pharyngeal teeth, diamond shaped exposed scale fields, scapular bar behind opercle and above pectoral fins, and usually yellow to orangebronze under parts. Also, dorsal head tubercles large, erect or slightly antrorse, caudal peduncle scales above and below lateral line with small edge spinelets, those under caudal peduncle with

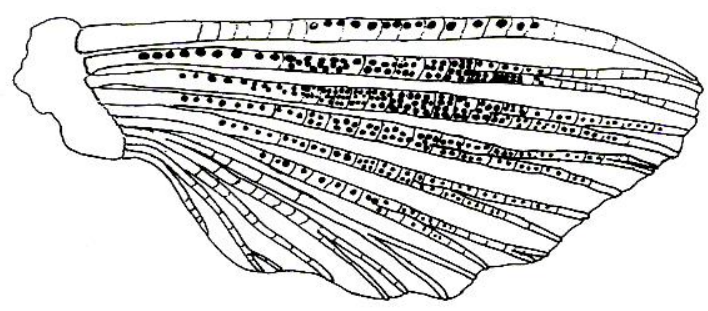

Fig. 3. Right pectoral fin of Cyprinella alvarezdelvillari n. sp., paratype UANL 8303, $35.0 \mathrm{~mm}$ SL, from Balneario La Concha, Durango, México. Colls. S. Contreras-Balderas, and FCB Group (SCB 88-58). Note concentration of tuberclets on first $4-5$ rays and around middle of their length, up to three lines along ray, and one to eight tuberclets per line on each segment. Sketch by A. Contreras-Arquieta and S. Contreras-Balderas.

scattered central tuberclets in a shagreen patch extending 1-2.5 (up to 3) scale rows above midventral row, extending from anal base to caudal base, and a scalloped edge of preopercle.

This species appears closer to the proserpina species pair, especially to $C$. panarcys, sharing with it the subdivisions of infraorbitals (IO) 23 ranging from IO 2 not subdivided to IO 3 divided in 2-3 (one specimen had two on one side, three on the other), a vomer with a deep anterior notch, and no autopterotic spine; although it shares some characters with the rutila species pair (hiatus between labial and interorbital tubercles and deep body). From the lep$i d a$ species group, it differs in apparently not having purplish hues and in being orange-bronze (often reddish) rather than yellow, although it shares with $C$. lepida the anterior basihyal ligament but incomplete rather than complete. From both the rutila and proserpina species pairs, it differs in having some marginal spinelets on dorsalmost scale row of caudal peduncle, agreeing with $C$. xanthicara in having up to three tuberculate scale rows above the lower-most caudal peduncle scale row.

Cyprinella alvarezdelvillari diverges from the rutila species pair in having at least a few tubercles on the lachrymal and large central tubercles on caudal peduncle scales; frequently submarginal or edge tubercles are the larger. It differs from the proserpina species pair in having the supralabial hiatus in tuberculation. It is close to C. panarcys in characters shown in Table 2 , plus having the deep anterior notch in vomer in the irregular subdivision of infraorbitals (from 0-3 subdivisions) and in the absence of the autopterotic spine.

All the numbered features possesed by $C$. alvarezdelvillari, except white fin borders, were considered by Mayden (1989) as primitive or 
COPEIA, 1994, NO. 4

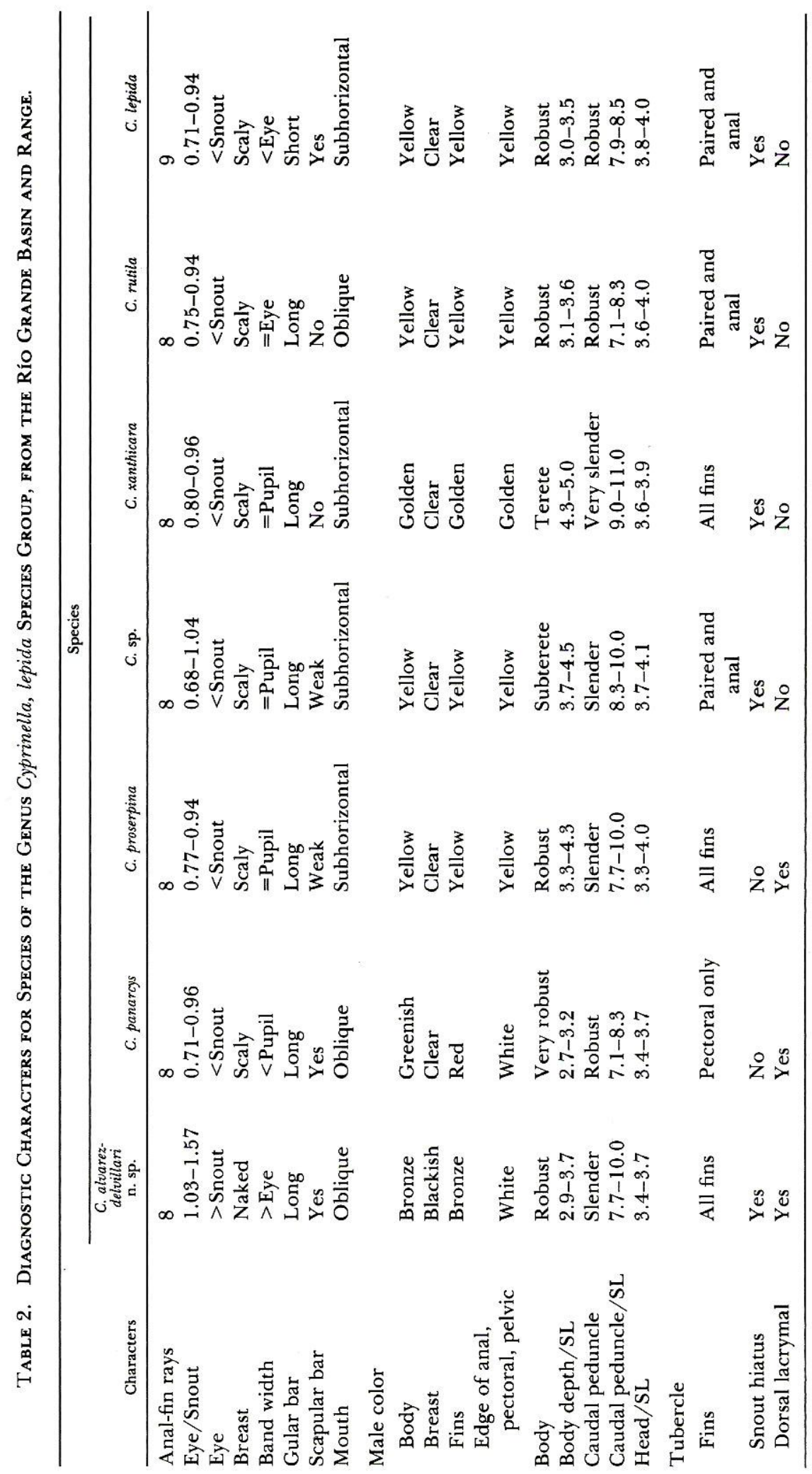


Table 3. Comparison of Three Shiners from Río Nazas, Mexican Central Plateau, Based Mostly on Male Characters.

\begin{tabular}{|c|c|c|c|}
\hline & $\begin{array}{l}\text { Cyprinella } \\
\text { alvarezdelvillari } \\
\text { n. sp. }\end{array}$ & $\begin{array}{l}\text { Cyprinella } \\
\text { garmani }\end{array}$ & $\begin{array}{l}\text { Codoma } \\
\text { ornata }\end{array}$ \\
\hline Anal rays & 8 & 10 & $7-8$ \\
\hline White border (P2,A,C) & Yes & Absent & Yes \\
\hline Lateral band & Present, wider than eye & Weak, only on peduncle & $\begin{array}{l}\text { Narrow, }=\text { pupil in } \\
\text { young and female }\end{array}$ \\
\hline Basicaudal spot & None & Weak & Yes \\
\hline $\begin{array}{l}\text { Basicaudal spot and humeral } \\
\text { bar }\end{array}$ & Nondistinguishable & Separate & Nondistinguishable \\
\hline Dark body bars & Humeral only, weak & Humeral only & 6-10 (no humeral) \\
\hline Spotted breast & Yes & No & No \\
\hline Melanophores on venter & Heavy, both sexes & None & Heavy on males \\
\hline $\begin{array}{l}\text { Tuberculation dorsal/caudal } \\
\text { fins }\end{array}$ & Yes & Dorsal yes, caudal no & $\begin{array}{l}\text { Weakly on dorsal, cau- } \\
\text { dal none }\end{array}$ \\
\hline $\mathrm{Pl}$ & $\begin{array}{l}\text { Strong, } 2-5 \text { per seg- } \\
\text { ment }\end{array}$ & Weak, one per segment & Weak, one per segment \\
\hline Color of breeding males & $\begin{array}{l}\text { Bronze to black, never } \\
\text { barred }\end{array}$ & $\begin{array}{l}\text { Blue dorsum, red un- } \\
\text { derparts }\end{array}$ & Gray to black, barred \\
\hline
\end{tabular}

reversals to primitive traits, an interesting observation for our new species, that is peripheral to its group, i.e. occupying Río Nazas which is not actual part of Río Grande, although it is considered detached and derived from the Pleistocene Río Grande (Meek, 1903, 1904; Farrington, 1904), all others being actual Río Grande forms, except $C$. lepida. We have observed several peculiarities, such as the shape of the hypural complex, to be reported elsewhere. It is not our intention to do a full osteological comparison, it should await a revisionary study of the species group, beyond the scope of this paper. Two other species referred recently to Cyprinella, C. garmani and C. ornata, are roughly sympatric and have been confused with C. alvarezdelvillari n. sp.; C. garmani is parapatric to the new species. Codoma ornata, considered by Mayden (1989) to be a Cyprinella, was regarded as a valid genus by $\mathrm{S}$. ContrerasBalderas and W. L. Minckley (MS) based on gross morphology and behavior; and ContrerasBalderas (1975) suspected it not to be a Notropis, hence used the name between quotation marks. The view was held by Contreras-Balderas (1978) and Miller (1978) without further comment, and we keep this use here. A comparison with these two species appears in Table 3.

Table 4. Associated Species of Fishes and Selected Habitat factors in Collections of Cyprinella alvarezdelvillari $\mathbf{N}$. SP.

\begin{tabular}{|c|c|c|c|c|c|c|}
\hline \multirow[b]{2}{*}{ Temperature (C): } & \multicolumn{2}{|c|}{ La Concha } & \multirow[b]{2}{*}{$\begin{array}{l}\text { Belém } \\
29\end{array}$} & \multicolumn{3}{|c|}{ Peñón Blanco } \\
\hline & Above 32 & Below 32 & & $\begin{array}{c}4 \mathrm{~km} \text { upstream } \\
25\end{array}$ & $1 \mathrm{~km}$ upstream & $\begin{array}{c}\text { At town } \\
20\end{array}$ \\
\hline Area & Spring & Outlet & Creek & Creek & Creek & Creek \\
\hline Water movement & Lentic & Lotic & Lotic & Lotic & Lotic & Lentic \\
\hline Astyanax sp. & 12 & 0 & 0 & 47 & 136 & 4 \\
\hline C. alvarezdelvillari & 1 & 286 & 172 & 12 & 1 & 0 \\
\hline Campostoma ornatum & 0 & 0 & 0 & 1 & 0 & 3 \\
\hline Gila c. conspersa & 0 & 2 & 21 & 99 & 311 & 234 \\
\hline Codoma ornata & 0 & 0 & 78 & 567 & 132 & 10 \\
\hline Cyprinodon nazas & 80 & 159 & 7 & 5 & 86 & 24 \\
\hline Pantosteus plebeius & 0 & 0 & 1 & 1 & 1 & 14 \\
\hline Ictalurus ca. pricei & 0 & 0 & 4 & 2 & 5 & 0 \\
\hline Etheostoma pottsi & 0 & $0^{*}$ & 0 & 0 & 0 & 1 \\
\hline Tilapia mossambica & 0 & 138 & 129 & 0 & 0 & 0 \\
\hline Collection year & 1988 & 1988 & 1988 & 1981 & 1968 & 1975 \\
\hline
\end{tabular}

* Collected in this locality in 1993. 


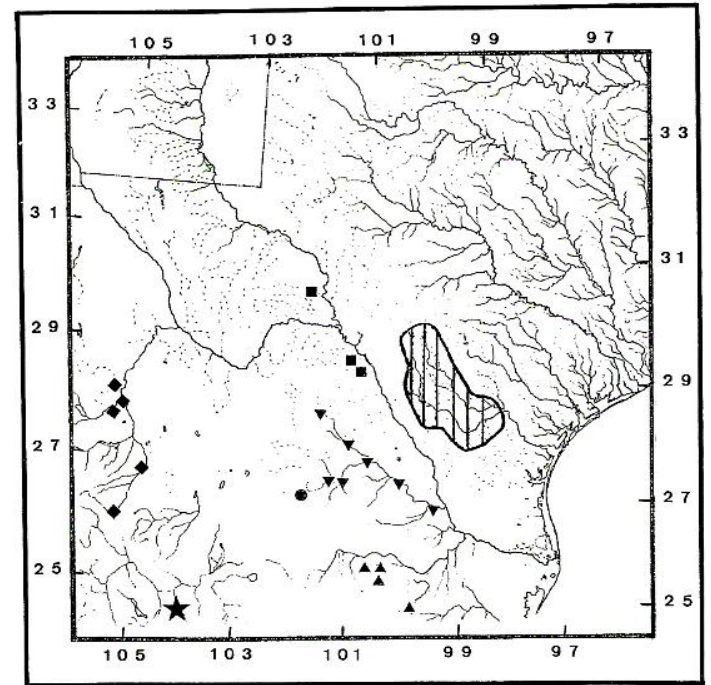

Fig. 4. Distribution of the cyprinid fishes of the genus Cyprinella lepida species group, in Texas and México: $\star$ C. alvarezdelvillari, Río Nazas; $\$ C. panarcys, Río Conchos; 1 C. proserpina, Pecos River; $\nabla$ Cyprinella sp., Río Salado; @ C. xanthicara, Cuatro Ciénegas; $\boldsymbol{\Lambda}$ C. rutila, Río San Juan; striped area: C. lepida, Nueces-Frío rivers.

Distribution.-Cyprinella alvarezdelvillari $\mathrm{n} . \mathrm{sp}$. is known only from Ojo La Concha and its outlet to $8 \mathrm{~km}$ downstream in the Arroyo del Peñón Blanco; it has not been collected at the town of Peñón Blanco or below. The creek flows in the Río Nazas (Fig. 4).

Habitat and associate species.-Arroyo del Peñón de Covadonga is a creek fed by thermal springs, $32 \mathrm{C}$ and warmer at the source. In Balneario La Concha, the stream gradually cools and runs over gravel and boulders (rarely over sand or mud) and is fast moving except where dammed. It has few pools, except for a large headpool widened by a dam, with a couple of swimming pools immediately downstream. Plants present, but not very abundant, are Polygonum, Bacopa, Eleocharis, Najas, and algae, all common around La Concha and scarce or absent at Belém. $C y$ prinella alvarezdelvillari is more common in flowing waters, away from plants, pools and mud; it avoids stagnant thermal waters near the spring pools, where it has been collected twice (one specimen each), but is abundant at a series of falls immediately below the Balneario (Table 4). The species is dominant in collections from moving water warmer than $29 \mathrm{C}$ (rare in lentic areas or at lower temperatures), syntopic with Cyprinodon nazas and the introduced Oreochromis mossambicus. It is not known to occur at temperatures lower than $25 \mathrm{C}$, where the fish fauna is dominated by Codoma ornata, Gila c. conspersa, and Astyanax sp. (Table 4).

Distributional comments on Cyprinella proserpina.-The distribution of Cyprinella proserpina has been given as the Pecos, Las Moras, and San Felipe rivers in Texas, and Río San Carlos (= Arroyos de Zorra, Lobo, Tule), in Coahuila, México. It is recorded herein as inhabiting Río San Rodrigo (= Río San Diego), a minor tributary draining the Río Grande $59.8 \mathrm{~km} \mathrm{SSE}$ from Cd. Acuña and $32.8 \mathrm{~km}$ SSE from Río San Carlos. This area of northeastern Coahuila, comprising the Río Morelos, Río de Nava, the mentioned Texan rivers, and others, has a distinctive fish community shared with the Pecos River, of which this species is a member. This region of Texas has been referred to as the Balconian biotic zone (Hubbs 1957; Smith and Miller, 1986). Cyprinella proserpina is the only species in its clade to occur both north and south of the main channel Río Grande.

\section{KEY TO THE Cyprinella lepida SPECIES GROUP}

1a. Gular bar short, usually reaching a point below mideye. Anal rays usually 9 ...................... lepida, Río Nueces, Río Frio

lb. Gular bar extending to edge of branchiostegal membranes. Anal rays usually 8 -........ 2a. Eye diameter larger than snout. Lateral band as wide or wid
than eye. Large isolated melanophores on naked breast. than eye. Large isolated melanophores on naked breast. ...... alvarezdelvillari n. sp., Río Nazas

2b. Eye shorter than snout. Lateral band narrower or equal to eye (in rutila). No large melanophores on scaled breast ............. 3 . eye (in rula). No large melanophores on scaled breast

3b. Hiatus present between labial and interorbital tuberclets..5

4a. Mouth oblique. Body high, 2.7-3.2 in SL. Pectoral, pelvic, and anal fins of mature males red, with white borders panarcys, Río Conchos

b. Mouth nearly horizontal. Body slender, 3.3-4.3 in SL. Pectoral, pelvic, and anal fins of mature males plain yellow to toral, pelvic, and anal fins of mature males plain yellow to
golden .. proserpina, Río Pecos, Río San Carlos, Rio San Rodrigo (new record).

a. Body robust, 3.1-3.6 in SL. Caudal peduncle slender, 7.1-

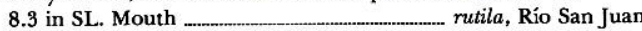

5b. Body slender, 3.7-5.0 in SL. Caudal peduncle very slender, 8.3-11 in SL. Mouth subhorizontal

6a. Lateral band jet black. Head small, 3.6-3.9 in SL xanthicara, Cuatro Ciénegas

6b. Lateral band well marked, not jet black. Head midsized, $3.7-$ 4.1 in SL

........ Cyprinella sp., Río Salado. (this species under study by R. R Miller and the authors of this paper)

\section{Comparative Material Examined}

Cyprinella lepida: TEXAS: TNHC 5279 (63: $33.5-46.6 \mathrm{~mm} \mathrm{SL})$; Edwards-Uvalde line, E Nueces River, United States.

Cyprinella panarcys: DURANGO: UANL 501 (1: $23.4 \mathrm{~mm} \mathrm{SL})$, Río Florido at Nieves, Dgo., 24-VI-64. CHIHUAHUA: UANL 2166 (251: 31.4-36.6 mm SL), Río San Pedro at Meoqui. 24-VIII-68. UANL 2250 (1: $52.3 \mathrm{~mm} \mathrm{SL}$ ), same locality, 2-VIII-68. UANL 5571 (41: 26.0-34.9 mm SL), Río Chuviscar at San Diego, 29-VII-82.

Cyprinella proserpina: TEXAS: TU 3647 (13), Independence Creek, near Sheffield, 11/VI/52. COAHUILA: UANL 1388 (9: 30.6-45.6 $\mathrm{mm}$ SL), Río San Rodrigo $32.6 \mathrm{~km}$ N Morelos (new record), 6-VIII68.

Cyprinella rutila: NUEVO LEON: UANL 152 (1: $35.7 \mathrm{~mm} \mathrm{SL})$, Ar- 
royo Chapultepec, $4 \mathrm{~km}$ NE Guadalupe, 5-VII-62. UANL 648 (228: 13.8-51.1 mm SL), Río Pilón ca. Montemorelos, 21-VII-64. UANL 616 (191: 16.6-45.3 mm SL), Arroyo $2.5 \mathrm{~km} \mathrm{SW} \mathrm{El} \mathrm{Ranchito,} \mathrm{Santiago,}$ 23-VII-64. UANL 766 (1), Río de la Silla, La Pastora, Guadalupe, 3-X61.

Cyprinella sp.: COAHUILA: UANL 688 (77), Estación Polka, 26VIII-64. UANL 697 (135: 29.9-65.7 mm SL), Río Salado de Nadadores $16 \mathrm{~km}$ W Nadadores, 26-VIII-64. NUEVO LEON: UANL 439 (22 26.3-46.0 mm SL), Ojo de Agua in Sabinas Hidalgo, 17-VI-64. UANL 8507 (7: 29.9-39.9 mm SL), Río Salado at Rancho El Garceño, 9-IX 84. UANL 8839 (3: 35.3-40.2 mm SL), Rio Salado at Sifón de Villanueva, 4-VI-85. TAMAULIPAS: UANL 8593 (2: 22.2-32.5 mm SL), Rio Salado at Los Olmos, 11-XI-84.

Cyprinella xanthicara: UANL 801 (25: $21.5-45.6 \mathrm{~mm} \mathrm{SL})$, Arroyo 9.4 km SSW Cuatro Ciénegas, 29-XII-65. UANL 6175 (40: 15.7-47.0 mm SL), Río Garabatal, 8-VIII-68.

\section{ACKNOWLEDGMENTS}

This study was made possible through the cooperation of many colleagues, students, and administrators. The following persons provided specimen loans or data: D. A. Hendrickson, R. R. Miller, W. L. Minckley, R. D. Suttkus. The manuscript was critically read by F. Abarca, W. L. Minckley, and E. P. Pister. R. Bart and D. A. Hendrickson verified some characters and collection records. Numerous persons helped to collect materials used in this study: C. D. Barbour, C. Hubbs, D. Pettus, A. Solórzano, S. H. Weitzman, and former or actual UANL personnel J. Alvarado-O., P. Barrón-R., J. CastilloT., A. Contreras-A., D. Contreras-A., A. J. Contreras-B., L. Contreras-B., O. GonzálezD.L., H. Medina-P., H. Obregón-B., J. L. Puente-F., J. M. Torres-A., J. Verduzco-M., G. Villarreal-V., and others. The manuscript was typed by M. T. Guadarrama-C. Figure 1 was photographed by J. L. Gibaja. A. Contreras-A. assisted in drawing Figure 3 and in computing tables. Collecting permits were provided in 1963, $1964,1968,1975$, and 1982 by the then Departamento de Pesca. Financial assistance was given to SCB by CONACYT in 1986-1988 (Project PCECBNA 021381) and to MLLV in 1987-1988 by SEP-DGICSA (Projects C87-080199 and C88-08-0128). To all the persons and institutions mentioned, we express our deepest appreciation.

\section{Literature Cited}

Chernoff, B., AND R. R. Miller. 1982. Notropis bocagrande, a new cyprinid fish from Chihuahua, Mexico, with comments on Notropis formosus. Copeia 1982:514-522.

Contreras-Balderas, S. 1975. The zoogeography and evolution of Notropis lutrensis, and "Notropis" ornatus in the Rio Grande basin and range, Mexico and United States (Pisces: Cyprinidae). Unpubl. Ph.D. diss., Tulane Univ., New Orleans, Louisiana.

- 1978. Speciation aspects and man-made community composition changes in Chihuahuan desert fishes, p. 405-431. In: Transactions-symposium on the biological resources of the Chihuahuan Desert region, U.S. and Mexico. R. H. Wauer and D. H. Riskind (eds.). U.S. Nat. Park Serv., Trans. Proc. Ser. 3(1977), Washington, D.C.

Espinoza-Pérez, H., M. T. GasPar-Dilllanes, AND P. Fuentes-Mata. 1992. Listados faunísticos de México. III. Los peces dulceacuícolas mexicanos. Publicaciones Especiales, Universidad Autónoma de México.

FarRington, O. C. 1904. Observations on the geology and geography of Western Mexico, including an account of the Cerro Mercado. Field Columbian Mus. Geol. Ser. 2:197-228.

GIRARD, C. 1857. Researches upon the cyprinoid fishes inhabiting the fresh waters of the United States, west of the Mississippi valley, from specimens in the Museum of the Smithsonian Institute. Proc. Acad. Nat. Sci. Philadelphia 8:165-213 (for 1856).

Hunss, C. 1957. Distributional patterns of Texas freshwater fishes. Southwest. Nat. 2:89-104.

HubBs, C. L., AND K. F. Lagler. 1964. Fishes of the Great Lakes region. Univ. of Michigan Press, Ann Arbor.

-, AND R. R. MiLler. 1978. Notropis panarcys, n. sp. and $N$. proserpinus, cyprinid fishes of the subgenus Cyprinella, each inhabiting a discrete section of the Rio Grande complex. Copeia 1978:582-592.

KAFUKU, T. 1958. Speciation in cyprinid fishes on the basis of intestinal differentiation with some references to that among catostomids. Bull. Freshwater Fish. Res. Lab. 8:45-78.

Leviton, A. E., AND R. H. GibBs, JR. 1988. Standards in herpetology and ichthyology. Standard symbolic codes for institution resource collections in herpetology and ichthyology. Supplement No. 1: additons and corrections. Copeia 1988:280-282.

, E. Heal, and C. E. Dawson. 1985. Standards in herpetology and ichthyology: Part. I. Standard symbolic codes for institutional resources collections in herpetology and ichthyology. Copeia 1985:802-832.

Matthews, W. J. 1987. Geographic variation in $C y$ prinella lutrensis (Pisces: Cyprinidae) in the United States, with notes on Cyprinella lepida. Copeia 1987: 616-637.

Mayden, R. L. 1989. Phylogenetic studies of North American minnows, with emphasis on the genus Cyprinella (Teleostei: Cypriniformes). Misc. Publ., Mus. Nat. Hist., Univ. of Kansas 80:1-189.

MeEK, S. E. 1903. Distribution of the fresh-water fishes of Mexico. Amer. Nat. 37:771-784.

. 1904. The fresh-water fishes of Mexico north of the Isthmus of Tehuantepec. Field Columbian Mus. Zool. Ser. 5:1-252.

MILLER, R. R. 1978. Composition and derivation of the native fish fauna of the Chihuahuan Desert region, U.S. and Mexico, p. 365-381. In: Transactions-symposium on the biological resources of the Chihuahuan Desert region U.S. and Mexico. R. H. Wauer and D. H. Riskind (eds.). U. S. Natl. Pk. Serv., Trans. Proc. Ser. 3(1977), Washington, D.C. Minckley, W. L., AND G. L. LyTLE. 1969. Notropis xanthicara, a new cyprinid fish from the Cuatro Cie- 
negas basin, north-central Mexico. Proc. Biol. Soc. Washington 82:491-502.

Smith, M. L. AND R. R. Miller. 1986. The evolution of the Rio Grande Basin as inferred from its fish fauna, p. 457-485. In: The zoogeography of North American freshwater fishes. C. Hocutt and E. O. Wiley (eds.). J. Wiley and Sons, New York, New York.

Williams, J. E., J. E. Johnson, D. A. Hendrickson, S. Contreras-Balderas, J. D. Williams, M. Navarro-M., D. E. McAllister, and J. E. Deacon. 1989. Fishes of North America endangered, threatened, or of special concern: 1989. Fisheries $14: 2-20$.

Facultad de Ciencias Biológicas, Universidad Autónoma de Nuevo Léon, AparTado Postal 504, SAN Nicolás de los Garza, N.L., MÉxico, 66450. Send reprint requests to SCB. Submitted: 16 April 1993. Accepted: 9 Dec. 1993. Secion editor: R. Winterbottom. 